\title{
＜原、啫 $>$
}

\section{社会規範と洒值の補強に及㴗すスポーツ \\ の正機能に関する一考察}

\author{
藤原健固* \\ （昭和49年 4 月 18 日受付）
}

\begin{abstract}
A Study of the Function of Sports for the Reinforcement of Social Norms and Values
\end{abstract}

\author{
Kengo Fujiwara \\ (Chukyo University)
}

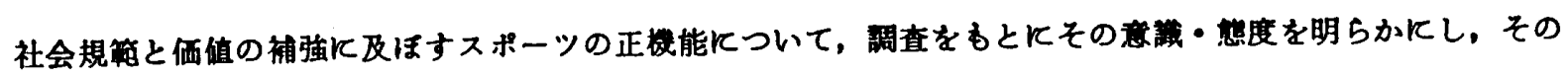
背景を孝察して。

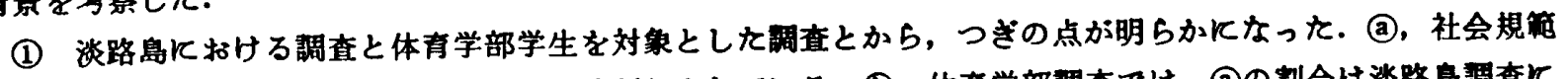

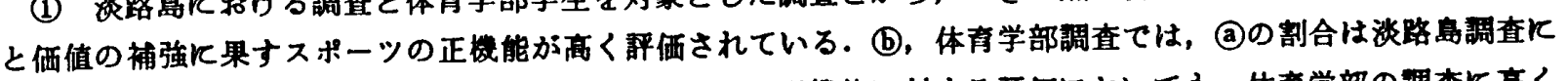

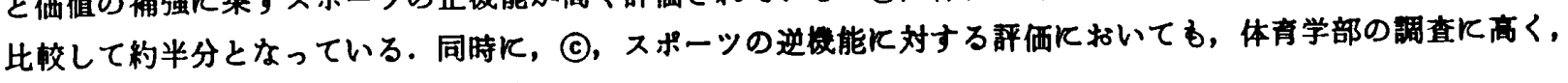
淡路岛でのスポーツ加者がれに梘いている。

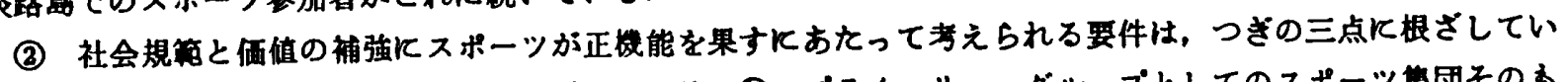
ろ. (a)、スポーツが, 本来, 社会化化関係している. (b、ブライマリー・グループとしてのスポーツ集团そのる ののすっている機能. および，スポーツ自体の内包する站争・協同の奻果.これらの要件を(1)の結果を踏まえ て考察した桔果, 若干の問題点が指摘された。

In this stuy, the functions of sports for the reinforcement of social norms and values were examined, and it's backgound considered. Some findings are as follows.

(1) From the survey of the people of Awajishima and the students of a Department of Physical Education, next three points were found : (a) the function of sprts for the reinforcement of social norms and values is appraised higher than it's dys-function; (b) according to the survey of physical education majors, the rate of (a) was about half of the case at Awajishima; at the sametime, (c) the evaluation of dys-function of sports for the reinforcement of social norms and values was high among physical education majors.

(2) The backgrounds of function of sports for reinforcement of social norms and values were found to come from next three points: (a) primarily, the relationship between sport and socialization was recognized;(b) the sport group has the function as primary group in contemporary society; and, (c) the sport itself has the effect of competition and cooperation.

Having in mind the comparison between these backgrounds and these of findings of findings of survey, some unsolved problems were pointed out.

(kengo Fujiwara : "A Study of the Function of Sports for the Reinforcement of Social

中京大学 
Norms and Values," Research Journal of Physical Education, Vol. 19. No. 4.5, December, 1974, pp. 175 188)

\section{样}

スポーツの目槚を社会規筑と価值の補強に求め よ5とする考えは，除々に強調されつつある，そ れは歴史的社会的背景を基盤にしているが，とく に1910年代のアメリカにおいで，またわが国の 場合，大正の初期においで提示されるよ5にな ったそして，今日，スポーツの人間的側面の重 視は，社会規箐と価値の補強を度外視しては考え られないのである.

社会規籍 (Social Norms) とは，社会的人間と しての個人が思考様式・行動様式の是非善悪を評 価する基算であり，「その淵源や，その㟟反への 制裁み」に罢打ちされたものである。具体的には， 惯習・モーレス・法律・道徳・エチケット・伝統 などをその内容とする.

価值 (Values) とは，何らの欲求を充足させる 客体むしくはその性筫を指しており，それを獾得 ナる過程において何らかの特牲と排除に衰打ちさ れたものである．M・ウェーバーの表現をかりれ ば，「価值の実現を目さして，一時的な街動を押 充，エネルギーを系統的に配分していく行動のシ リーズ，すなわち，〈価值合理的行為〉"」を生 むあのである.

社会規籁と価值の補強 (reinforcement of social norms and values)——期待される社会的人間の 形成一は，教育（文化の得得）飞真わされてお り，それは主として世界観と秩序の問題にかかわ っている.この際，世界観は超越的な存在とのか かわりを意味し，秩序は目標志向の体系の内部で の諸监位がどのように調和すべきかを示す規隼で ある.

社会規筙と価值の㭪強に対するスポーツは，精 神的次元での快活・哃媇・埾忍持久などを背最に している. それは身体活功と精神活動の相即性に 基ついていることは言を㑨たない「筋内を活功 せしむるばかりでなく，筋肉その他身体における 重要なる器管はるよりり，精神をも発達せしむ る゙」とい5とき，スポーツの人間的側面は社会
规箅と価值の㭪強へのパースベクティブを閒いて いるものとして重視されなければならないので ある。

しかしながら，社会規螌と価值に対するスポー ッの機能 (functions) について二通りの見方が存 在するのが現実である。そその一は社会規籍と価値 の㭪強にスボーッの樻極的意義を認めよ5とする るのであり，他はそれを否定するるのである．そ れはとりるなおさず, スポーツの正機能 (function）と逆機能 (dysfunction) のどちらを重くみる かとい5問題である.

本稿の目的は，つぎの二点にある.

(1) 社会規籍と価值の㭪強に果し得るスポーツ の機能に対して如何なる意識・態度が指摘され得 るか.

(2) (1)で明らかにされた態度を可能ならしめる 基本的要件は何か.

本稿で用いた「機能」とい5用語の及占範盲 は，主として意識の次元のものであり，結果とし てのそれを意味しないの．この点において「正味 の差引き勘定" 」としての機能は，当然制約を免 れない.

\section{查方法}

本稿で用いた料は，『スポーツ棇合調査』の5 ちく社会規範と価值の補強に及ぼすスポーツの機 能>に関連する部分に限られる。「スボーツ総合 調査』は下記の要領で実施された。

（1）被調查者 (845名)

(1) 兵庫県，淡路島のコミュニティ・スボーツ

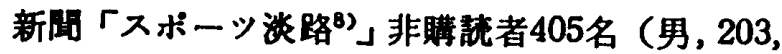
女 202)， 同購語者 240 名（男145，女95), 計 645 名.（資料 1 参照）

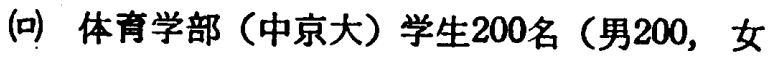
0)

(2) 調查方法 無作意抽出法によるアンケート調査.

(3) 調查時期

昭和 48 年10月 25 日～昭和 48 年 12 月 20 日 
料 1 被調盗者分類一淡路岛

\begin{tabular}{|c|c|c|c|c|c|c|c|c|c|c|c|c|c|c|}
\hline \multicolumn{8}{|c|}{ 「スポーツ淡路」非購鿁者 } & \multicolumn{7}{|c|}{ 「スポーツ淡路」睛読者 } \\
\hline $\begin{array}{l}\text { 年 } \\
\text { 性〉代 } \\
\text { 别 }\end{array}$ & 10代 & 20 代 & 30代 & 40 代 & 50代 & 定花 & 全体 & 10 代 & 20 代 & 30 代 & 40 代 & 50代 & 定高 & 全体 \\
\hline 鸟 & 49 & 10 & 33 & 50 & 36 & 25 & 203 & 40 & 9 & 19 & 50 & 10 & 17 & 145 \\
\hline 女 & 50 & 7 & 50 & 54 & 16 & 25 & 202 & 34 & 4 & 13 & 19 & 8 & 17 & 95 \\
\hline
\end{tabular}

\section{(4) 調査内容}

『スポーツ総合調查』の5ち主として「スポー ッに対する態度調査」の中から18項目を抽出. （本稿では便宜上，(1)，(口)に分けて整理記述し た.)（資料 2)

\section{结果}

（1）兵庫県・淡路島社会規範之価値の補強に及 ぼすスポーッの機能に対する意識・態度は，資料 3，4のとおりである.

これらの瓷料は，スポーツが社会規範と価值の 補強に積極的役割を果していることを支持するも のである。すなわち，全体では約 $65 \%$ の人が社会 規箸と価值の補強にスポーツが積極的側面を有し ているとのブラス評価（おおいに賛成 5 ，賛成 4 ） をしており，マイナス評価（おおいに反対 1 ，反 対 2 ) は5\%に過ざないのである.こ5したスポ 一ツの社会規筑と価侹に対する積極的役割の支持 は，その消極的倒面に対するマイナス評洒に葨打 ちされている。すなわち，スポーツが社会規箐と 価值の補強に役立たないとするものの割合は僅か に12\%に過ぎなのである：しかしながら，消極 的側佰を積極的に否定するものは，必らずしも多 くはなく，半分に過ぎない，ちなみに「どちら であない」とするものは, 37\%である.

さらに，社会規筑と価值の補強に及ぼすスポー ッの機能に対する意識・態度をみる場合，口一カ ル新聞「スポーツ淡路」の購読者や非辈読者につ いて検討する必要があろ5。まず，「積極的㑡面」 についてみると購諳者の方がブラス評価が高い。 ブラス評価で $6 \%$ 高く，「どちらであないよす る割合は $5 \%$ 高く， マイナス評価は同じである. このことは，「積極的側面」を支持する割合が 1 割程度非購読者に比へ漓いことを意味しているも
のと解してよいであろう．とくに，社会規範と価 值の補強を促進するための思考様式や行動様式を スポーツに求めよ5とする態度 (項目(1)-7), (8))，および社会性の開発 (項目(1)-(6)，(9)，(10) などにおいてこの傾向が認められた。つぎに、「消 極的側面」Kついてみると，購読者と非購読者と の間に大差を認め難いものの, ブラス評価とマイ ナス評価の双方においても購讜者の方が高い点が 注目される.このことは，睡読者においてスポー ッの「機能」に対する見方が多様であることを示 すものであり，同時に，「問題点”」を意識して いることを意味していると考えられる．スポーツ が社会規篂と価值の補強に役立たないとする根㧋 は，スポーツの技術的側面の偏重 (項目()-(4)), および封建的風土（項目回一(6)，(7)，とくに瞵珫 者）に求められている，とくに，封建的算害につ いての認識は非睛読者の女性に高い.

以上のことから二つの点が明らかになった．そ れは,

(1) 社会規範と価值の補強に対してスボーツは 正機能を果すものとして認識されていること.

(2) ロ一カル・スポーッ紙の䝼読者は非贈読者 に比較して，「積極的側面」をより高く支持して いる. しかし，「消極的側面」についての支持率 は，問題点を投げかけている.

そこで，(2)関してローカル・スポーツ紙の購 読者に与える機能が問われなければならないす なわち，購諳者と非購諳者との間においてスポー ッに対する見方が異なる要件は何か，とい5問題 である。それは主として二つの指標に求めること が可能である．その一は購語者の方が非購読者に 比べてスポーツにより多く接していることであ り，その二は䝼読者の方が非購読者に比べてスポ ーツについて上り梁く知っているといらことであ 
资料 2 社会規箱と価值の㭪强に及ぼすスポーツの機能調查項目

「扰願W」

あなたのスポーツに対する感じや意見について答えて下さい.

下KスポーツK対する意見が述であります，そして，1つの意見にそれそれ，5つの签えが用意しております。 見をよく誖んで，あなたの感じや意見によく合っていると思う答え（数字）を○でこんて下さい.

く例〉スポーツは人を感做させる

(1) 社会規策と価值の補强に及ほすスポーツの积亟的側面

(1) スポーツは，公正な人格をつくり人間性を典か Кする。

（2）人間は何か熱中することが必要であり，スポ 一ツはそれにもっともよくこたえるすのの一つ である。

(3) スポーツは，皆んなと仲よくやろろという気持 を青てる。

（4）スポーツは，青少年の非行防止に役立つ.

(5) スポーツは，教の久くことのできないーつの 頜域である。

（6）めまくるしく变化する社会にあってスポーツは 仲間への参加を通して集団の団桔をるたらす。

(7) スポーツは, 人閶がどのようК生き, 労闻し, 考えるかについてヒントを与える。

(8) スポーツは, 社会の期待している行䖝の指椤（も のごとの考え方・行ない方の基策）を提供する.

(9) スポーツマンは，社会の約東ごとやきまりをよ く守っていろ.

(10) スポーツは,人をひっぱっていく指㝵性（リー ダーシップ）をたかめる。

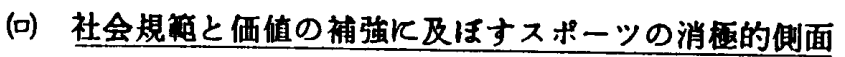

(1) スポーツは，人間を野ばんKし，俱った自信を うえつける。

(2) スポーツは，人間のるっている.たたかおうと する気持（阙争心）の一つの手段であり，あま り好ましいものではない。

（3）スポーツは，集った英雄甞拝をるたらす,

（4）スーポッは，身体的到较にかたより，精神的訓練 をなおざりにする傾问をすっている.

（5）スポーツは，自己諈美にかたより，うぬほれを つくりだす.

（6）スポーツは，従属的な人間をつくりだす.

(7) スポーツマンは, 封建的で粗野な人が括おい。

(8) スポーツは，柽率で考えない人間をつくる.

\begin{tabular}{|c|c|c|c|c|}
\hline 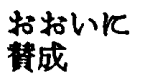 & 責成 & $\begin{array}{l}\text { どちらとも } \\
\text { いえない }\end{array}$ & 反対 & $\begin{array}{l}\text { お打いK } \\
\text { 反対 }\end{array}$ \\
\hline 5 & 4 & 3 & 2 & 1 \\
\hline 5 & (4) & 3 & 2 & 1 \\
\hline
\end{tabular}

4

3

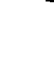

4

$\begin{array}{lll}3 & 2\end{array}$

32

$3 \quad 2$

3

21

3

3

$3 \quad 2$

$\begin{array}{ll}2 & 1 \\ 2 & 1 \\ 2 & 1 \\ 2 & 1 \\ 2 & 1 \\ 2 & 1 \\ 2 & 1 \\ 2 & 1\end{array}$




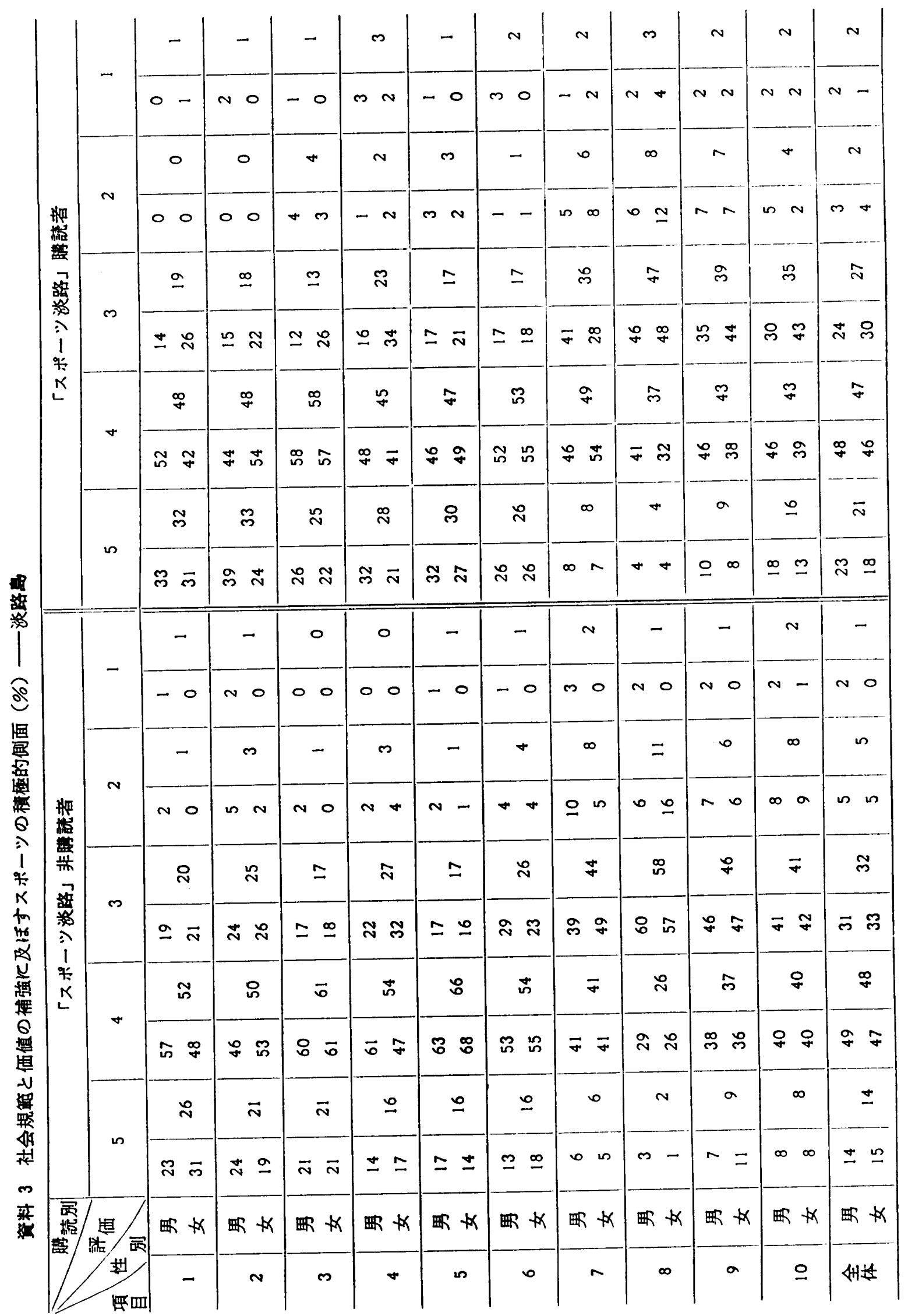




\begin{tabular}{|c|c|c|c|c|c|c|c|c|c|c|}
\hline \multirow{10}{*}{ 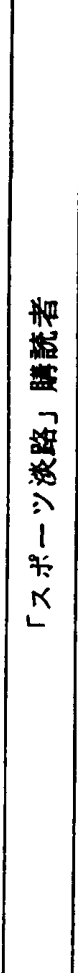 } & \multirow{2}{*}{-} & ల్ల & 은 & 으 & 2 & ㅇ & $\cong$ & $\simeq$ & $\simeq$ & 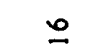 \\
\hline & & ల్ల & 으 = & 을 & 은 & $\infty \approx$ & $==$ & $\simeq \simeq$ & $\simeq 9$ & $\cong 2$ \\
\hline & \multirow{2}{*}{ N } & $\bar{\sigma}$ & $\stackrel{a}{N}$ & $\stackrel{2}{N}$ & $\bar{m}$ & ల్ల & $\stackrel{\infty}{\sim}$ & లి & $\$$ & ஜ \\
\hline & & \& 邑 & 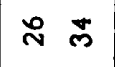 & 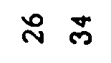 & 尺 & స్లె Б్ & స్ల జ & "ే5 우 & $9 \%$ & 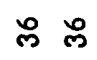 \\
\hline & \multirow{2}{*}{$m$} & $\stackrel{\infty}{-}$ & 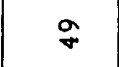 & $g$ & $\stackrel{m}{m}$ & $\hat{\text { s }}$ & $\approx$ & 8 & $\stackrel{\infty}{\sim}$ & $\ddot{m}$ \\
\hline & & $\underline{\sim} \bar{N}$ & 요 & i $\stackrel{\infty}{+}$ & $\stackrel{\infty}{m} \bar{m}$ & 今 & $\mp \%$ & F & 足 & ले मे \\
\hline & \multirow{2}{*}{$\sigma$} & $\infty$ & $a$ & $a$ & 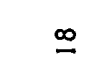 & $a$ & $\simeq$ & $\infty$ & $\underline{2}$ & $=$ \\
\hline & & $\infty \infty$ & 응 & 으 & 융 & 으 & $\simeq 2$ & $a$ is & $\simeq \simeq$ & $\simeq$ 은 \\
\hline & \multirow{2}{*}{$n$} & 0 & $N$ & $N$ & m & - & n & 0 & - & N \\
\hline & & 00 & $-n$ & +0 & in $N$ & no & $0 \mathrm{~m}$ & -0 & $\begin{array}{ll}n & 0\end{array}$ & $N-$ \\
\hline \multirow{10}{*}{ 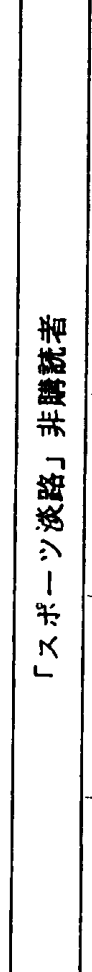 } & \multirow{2}{*}{-} & $\stackrel{\infty}{-}$ & $\simeq$ & 0 & n & $a$ & r & $=$ & 으 & 으 \\
\hline & & $\stackrel{\infty}{=}$ & $\simeq 2$ & $\sim 0$ & 0 & $\sim$ 으 & a in & 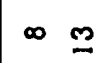 & 으으 & 으으 \\
\hline & \multirow{2}{*}{$\sim$} & $\stackrel{\infty}{*}$ & $F$ & $\bar{m}$ & i̊ & 우 & ले & లి & $\boldsymbol{q}$ & 우 \\
\hline & & $\overline{\text { sn }}$ & $\bar{\sigma} \stackrel{\infty}{+}$ & సิ న్ & ह్ల & $F$ gे & sి & ని జ & \% & 요 \\
\hline & \multirow{2}{*}{$m$} & $\mathscr{N}$ & मे & in & F & q & $\hat{f}$ & $\$$ & हे & ले \\
\hline & & $\tilde{N}$ & జ్ల & ํํ ก & พ 8 & F & F $\overline{\text { sn }}$ & $\%$ & $\stackrel{\infty}{\infty} \bar{m}$ & 今े \\
\hline & \multirow{2}{*}{+} & $a$ & in & $a$ & $\underline{m}$ & 으 & 으 & n & 0 & $a$ \\
\hline & & $n=$ & $n+$ & $=r$ & 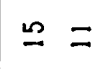 & $\sim \underline{m}$ & $\infty \underline{m}$ & $\sim 0$ & 00 & a a \\
\hline & \multirow{2}{*}{ in } & N & - & m & $N$ & N & $N$ & m & - & $n$ \\
\hline & & $\sim N$ & $N-$ & $m N$ & $m-$ & $-N$ & $N N$ & $\sim m$ & $0 \mathrm{~N}$ & $N N$ \\
\hline & 政 & 㧽 & 㧽 & 政 & 略 & 凅 & 㧽 & 晒 & 㺵 & 吅 \\
\hline & & - & N & m & + & n & 0 & n & $\infty$ & $\langle H+4$ \\
\hline
\end{tabular}




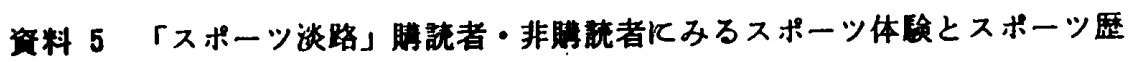

\begin{tabular}{|c|c|c|c|c|c|c|c|c|c|c|c|c|c|c|c|c|}
\hline \multirow{2}{*}{\multicolumn{2}{|c|}{ 項 }} & \multicolumn{2}{|c|}{10 代 } & \multicolumn{2}{|c|}{20 代 } & \multicolumn{2}{|c|}{30 代 } & \multicolumn{2}{|c|}{40 代 } & \multicolumn{2}{|c|}{50 代 } & \multicolumn{2}{|c|}{ 定・高 } & \multicolumn{3}{|c|}{ 計 } \\
\hline & & 男 & $-k$ & 男 & 女 & 男 & 女 & 男 & 女 & 男 & 女 & 男 & 女 & 男 & 女 & 計 \\
\hline $\begin{array}{l}\text { 1ヶ月以内 } \\
\text { Kスポーツ } \\
\text { をした }\end{array}$ & $\begin{array}{l}\text { 賄 読 者 } \\
\text { 韭瞵読者 }\end{array}$ & 98 & 91 & 78 & $\begin{array}{l}75 \\
43\end{array}$ & 95 & 34 & 42 & 24 & $\begin{array}{l}20 \\
19\end{array}$ & $\begin{array}{l}38 \\
13\end{array}$ & $\begin{array}{r}100 \\
88\end{array}$ & $\begin{array}{r}100 \\
88\end{array}$ & $\begin{array}{l}76 \\
63\end{array}$ & $\begin{array}{l}65 \\
48\end{array}$ & \\
\hline $\begin{array}{l}\text { スポーツ歴 } \\
3 \text { 年以上 }\end{array}$ & 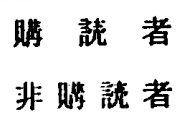 & $\begin{array}{l}68 \\
53\end{array}$ & 76 & 41 & $\begin{array}{l}75 \\
14\end{array}$ & 32 & 23 & 74 & 42 & $\begin{array}{l}80 \\
22\end{array}$ & $\begin{array}{r}25 \\
6\end{array}$ & $\begin{array}{l}82 \\
52\end{array}$ & $\begin{array}{l}82 \\
20\end{array}$ & $\begin{array}{l}67 \\
40\end{array}$ & $\begin{array}{l}52 \\
28\end{array}$ & \\
\hline
\end{tabular}

料 6 スポーツKついて相談をもちかけられた割合

(\%)

\begin{tabular}{|c|c|c|c|c|c|c|c|c|c|c|c|c|c|c|c|}
\hline \multirow[b]{2}{*}{ 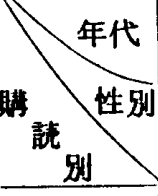 } & \multicolumn{2}{|c|}{10 代 } & \multicolumn{2}{|c|}{20 代 } & \multicolumn{2}{|c|}{30 代 } & \multicolumn{2}{|c|}{40 代 } & \multicolumn{2}{|c|}{50 代 } & \multicolumn{2}{|c|}{ 定・高 } & \multicolumn{3}{|c|}{ 計 } \\
\hline & 男 & 尖 & 男 & 女 & 男 & 女 & 男 & 女 & 男 & 女 & 男 & 女 & 男 & 女 & 計 \\
\hline 睡読者 & 40 & 18 & 44 & 0 & 58 & 15 & 50 & 21 & 30 & 0 & 24 & 24 & 41 & 13 & 27 \\
\hline 非睡諳者 & 24 & 12 & 31 & 0 & 40 & 13 & 8 & 9 & 8 & 0 & 8 & 12 & 20 & 8 & 14 \\
\hline
\end{tabular}

る.

資料 5 は，ローカル・スポーツ紙の購読者と非 購読者のスポーツ体駼とスポーツ歷の相異をみた ものである,「1カ月以内に何かスポーッをした」

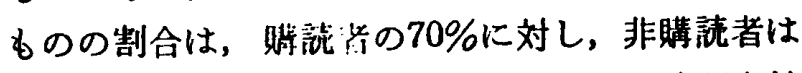
55\%である、ここで注意すべき点は，定時制高校 （定・闻）と10代の殆んどが生徒であることから 高い割合を示していることであるが，20代～50代 の割合をみても全作の傾向は変らない，すなわ ち，20代〜50代の全仆の割合は57\%であり，性別 では男66\%，女49\%である。これに対し非購読者 の20代〜50代の全作の割合は36\%であり，性別で は男48\%，女28\%である。また，スポーッ歴（3 年以上）について㐎と購読者 $60 \%$ ，非購読者 34 \%である.20ビ５0代までの購読者のそれは52\% であり，非盽珫背のそれは26\%に過ぎない，性別 で20代〜50代のスポーツ歴をみると䝼読者男63 \%，女18\%である.

資料 6 は, スポーツについて相談をるちかけら
れた割合をみたものである. 全体では20\%である が，購読者の方が非購読者に比べて䄪 2 倍を示し ている.とくに40代の男性50\%に対し，同代女性 は8\%に過ざい。このよ5に男性の方が高い割 合を示す傾向は瓷料 7 でも指揂し得るが，ここで む同様である.しかし，注目すべきは盗料 5 の男 女の比がほぼ10\%の差であるのに比へ，資料 6 の それは約30\%と高い点である.

以上の結果から，つぎの三点を指摘し得る.

(a賱訬者は非䝼䛨者に比較してスポーツに接触 する機会（值接参加）が豊富である，とくに，ス ポーツ歴では䁖読者は非購読者の 2 倍を示してい る. (口睡読者は非贌読者に比較してスポーッにつ いてよく知っている. (ㅁーカル・スポーツ紙の 果す機能が認められる. 全般にいえることである が，とくに10代，定・滈，の購読者, 非購読者の 示す差基に注目一いずれも購読者の方が滈い。 しかし、ローカル・スポーツ紙を読さからスポー ツ体験が豊かになるのか，スポーツ体験を得るこ 
资料 7 社会規符と価值の補強に及ほす スーポツの皘極的側面——体青学部学生

\begin{tabular}{|c|c|c|c|c|c|}
\hline 項目 & 5 & 4 & 3 & 2 & $: 1$ \\
\hline 1 & (11) & $\begin{array}{c}87 \\
(44)\end{array}$ & $\begin{array}{c}86 \\
(43)\end{array}$ & $\left(\begin{array}{l}2 \\
1\end{array}\right)$ & $\left(\begin{array}{l}4 \\
2\end{array}\right)$ \\
\hline 2 & $\begin{array}{c}50 \\
(25)\end{array}$ & $\begin{array}{l}106 \\
(53)\end{array}$ & $\begin{array}{c}38 \\
(19)\end{array}$ & $\left(\begin{array}{l}4 \\
2\end{array}\right)$ & $\left(\begin{array}{l}2 \\
1\end{array}\right)$ \\
\hline 3 & $\begin{array}{c}17 \\
(8.5)\end{array}$ & $\begin{array}{c}82 \\
(41)\end{array}$ & $\begin{array}{c}88 \\
(44)\end{array}$ & $\left(\begin{array}{l}8 \\
4\end{array}\right)$ & $\begin{array}{c}5 \\
(2.5)\end{array}$ \\
\hline 4 & $\begin{array}{c}25 \\
(12.5)\end{array}$ & $\begin{array}{l}114 \\
(57)\end{array}$ & $\begin{array}{c}55 \\
(27.5)\end{array}$ & $\left(\begin{array}{c}3 \\
(1.5)\end{array}\right.$ & $\begin{array}{c}5 \\
(0.5)\end{array}$ \\
\hline 5 & $\begin{array}{c}73 \\
(36.5)\end{array}$ & $\begin{array}{l}108 \\
(54)\end{array}$ & $\left(\begin{array}{c}18 \\
9\end{array}\right)$ & $\left(0 . \frac{1}{5}\right)$ & $\left(\begin{array}{l}0 \\
0\end{array}\right)$ \\
\hline 6 & $\begin{array}{c}27 \\
(13.5)\end{array}$ & $\begin{array}{c}131 \\
(65.5)\end{array}$ & $\begin{array}{c}37 \\
(18.5)\end{array}$ & $\left(\begin{array}{l}2 \\
1\end{array}\right)$ & $\begin{array}{c}3 \\
(1.5)\end{array}$ \\
\hline 7 & $\left(\begin{array}{l}12 \\
6\end{array}\right)$ & $\begin{array}{c}80 \\
(40)\end{array}$ & $\begin{array}{c}96 \\
(48)\end{array}$ & $\left(\begin{array}{c}10 \\
5\end{array}\right)$ & $\left(\begin{array}{l}2 \\
1\end{array}\right)$ \\
\hline 8 & (2. $\left.\begin{array}{c}5 \\
5\end{array}\right)$ & $\begin{array}{c}76 \\
(38)\end{array}$ & $\begin{array}{l}100 \\
(50)\end{array}$ & $\left(\begin{array}{c}16 \\
8\end{array}\right)$ & $\begin{array}{c}3 \\
(1.5)\end{array}$ \\
\hline 9 & (2. $\left.\begin{array}{c}5 \\
5\end{array}\right)$ & $\begin{array}{c}47 \\
(23.5)\end{array}$ & $\begin{array}{c}117 \\
(58.5)\end{array}$ & $\left(\begin{array}{c}21 \\
(10.5)\end{array}\right.$ & $\left(\begin{array}{c}10 \\
5\end{array}\right)$ \\
\hline 10 & $\begin{array}{c}20 \\
(10)\end{array}$ & $(43.5)$ & $\begin{array}{c}84 \\
(42)\end{array}$ & (3. $\left.\begin{array}{l}7 \\
5\end{array}\right)$ & $\left(\begin{array}{l}2 \\
1\end{array}\right)$ \\
\hline 計 & $\begin{array}{c}255 \\
(12.8)\end{array}$ & $\begin{array}{c}918 \\
(45.9)\end{array}$ & $\begin{array}{c}717 \\
(35.9)\end{array}$ & $\begin{array}{c}74 \\
(3.7)\end{array}$ & $\begin{array}{c}32 \\
(1.6)\end{array}$ \\
\hline
\end{tabular}

( ) $は \%$

とによってローカル・スポーツ紙に 接触するのか のメカニズムについては明らかではない（しか し，この問題についての考察は本稿の目的ではな W.)

（可体育学部学生 資料 7，8 は，社会規笓と 価值の㭪強に及ぼすスボーツの正機能に 対する体 育学部学生の調査結果である.

「正機能」に対する支持率をみると，全体では 59\%の学生がプラス評価をしており，マイナス評 価は $5 \%$ 過ぎない，ちなみに，「どちらでもな い」とするすのは 36\%である. 淡路島調查と同 様, ここでも「逆機能」に対するマイナス評洒は 高く，スポーツの社会規箱と価值に及ぽ正機能 を支持する結果を得た，全体でマイナス評価は46 \%であり，ブラス評価は $14.3 \%$ である。ちなみ に、「どちらであない」とするすのは39\%である. しかしながら，「逆機能」を積極的に否定するもの
资料 8 社会規箱と価値の補強に及ほす

スポーツの消梗的側面——体育学部学生

\begin{tabular}{|c|c|c|c|c|c|}
\hline 音 & 5 & 4 & 3 & 2 & 1 \\
\hline 1 & $\begin{array}{c}3 \\
(1.5)\end{array}$ & $\begin{array}{c}9 \\
(4.5)\end{array}$ & $\begin{array}{c}51 \\
(25.5)\end{array}$ & $\begin{array}{c}89 \\
(44.5)\end{array}$ & $\begin{array}{c}48 \\
(24)\end{array}$ \\
\hline 2 & $\begin{array}{c}3 \\
(1.5)\end{array}$ & $\left(\begin{array}{c}10 \\
5\end{array}\right)$ & $\begin{array}{c}43 \\
(21.5)\end{array}$ & $\begin{array}{c}123 \\
(61.5)\end{array}$ & $\begin{array}{c}21 \\
(10.5)\end{array}$ \\
\hline 3 & ( $\left.{ }^{6}\right)$ & $\begin{array}{c}34 \\
(17)\end{array}$ & $\begin{array}{c}96 \\
(48)\end{array}$ & $\begin{array}{c}56 \\
(28)\end{array}$ & $\begin{array}{l}8 \\
(4)\end{array}$ \\
\hline 4 & $\begin{array}{c}3 \\
(1.5) \\
\end{array}$ & $\begin{array}{c}33 \\
(16.5)\end{array}$ & $\begin{array}{c}74 \\
(37)\end{array}$ & $\begin{array}{c}72 \\
(36)\end{array}$ & $\begin{array}{l}18 \\
(19)\end{array}$ \\
\hline 5 & $\begin{array}{c}3 \\
(1.5) \\
\end{array}$ & $\begin{array}{c}38 \\
(19) \\
\end{array}$ & $\begin{array}{r}75 \\
(37.5) \\
\end{array}$ & $\begin{array}{c}72 \\
(36)\end{array}$ & $\left(\begin{array}{c}12 \\
6\end{array}\right)$ \\
\hline 6 & ( $\left.\begin{array}{l}2 \\
1\end{array}\right)$ & $\begin{array}{r}29 \\
(14.5) \\
\end{array}$ & $\begin{array}{l}108 \\
(54) \\
\end{array}$ & \begin{tabular}{|c|}
54 \\
$(27)$ \\
\end{tabular} & $\begin{array}{r}7 \\
(3.5) \\
\end{array}$ \\
\hline 7 & ( $\left.\begin{array}{l}4 \\
2\end{array}\right)$ & $\begin{array}{c}26 \\
(13)\end{array}$ & $\begin{array}{c}103 \\
(51.5)\end{array}$ & $\begin{array}{c}57 \\
(28.5)\end{array}$ & $\left(\begin{array}{c}10 \\
5\end{array}\right)$ \\
\hline 8 & $\begin{array}{l}8 \\
(4)\end{array}$ & $\begin{array}{c}28 \\
(14)\end{array}$ & $\begin{array}{c}74 \\
(37)\end{array}$ & $\begin{array}{c}68 \\
(34)\end{array}$ & (ii) \\
\hline 計 & $(2.1)$ & $\begin{array}{c}197 \\
(12.3)\end{array}$ & $\begin{array}{c}624 \\
(39.0)\end{array}$ & $\begin{array}{r}590 \\
(36.7)\end{array}$ & $\begin{array}{c}146 \\
(9.1)\end{array}$ \\
\hline
\end{tabular}

( ) $अ \%$

は，淡路島調查（51\%）より低く，46\%となって いる.

社会規箱と価值の㭪強にスポーツが 果す役割に ついてその積極的側面をより重視する見方は，淡 路島調查の方が高い，同様に，「逆機能」をより指 摘する割合は体育学部調查の方が高い，それは体 育学部学生の方が実際にスポーツにより多く参加 しており（とりわけ，35\%が競技スポーツ部員， スポーツの本来具有しているマイナス面を肌で感 じとっているからにほかならないといるるたろ 5.

とくに，現代の競技スポーツ志向への飽むこと のない追求は「誤った英雄崇拝」(項目(1)一(3)をる たらすもの (32\%) として受け取られ，その結果

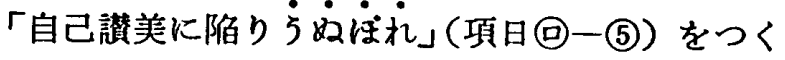
りだす $(20.5 \%)$ るのをする批判が強い。ちなみ に，淡路島調査では項目(1)-(3)，(5)に対する支持 率はとるに11.1\%である。そして，こ5したスポ 一ツのもたらす消極的侧面は，「怪率で考えない」 （項目回一(8)）人間をつくるものとして繁戒され 
ろ.（体育学部調查 $18 \%$ ，淡路島調查 $10 \%$ ）乙か しながら，「䦥争心」（項目回一(2)）に対する評 価は, 体育学部調查の方がイナス評価が低く 2 \%に過ぎないのに対し，汽路島調查では $8 \%$ を示 している.

「積極的侧面」についてみると、「教育の一環」 (項目(1)-(5) としての位罢つけが亩い，(86\%) また，「団結」(項目(1)一(6) への橋渡しとしてス ポーツを評価している（79\%)。ささらに，現代の 大衆社会状況下に拈いて「燃えること」(項目(1)一 (2)）の意義をスポーツに求めている傾向が強い $(78 \%)$. これらの項目に対する支持率は，いず れも体育学部調查の方が高い数值を示している. しかしながら，「規則を遵守」(項目(1)一(9) をス ポーツに求めよ5とする態度は比較的稀薄であ る $(26 \%)$. 換言すれば，4人の5ち1人は,“ル ールを守る”とい5スポーッマンシップの必須条 件の一つに信頼を扣いていないとい5ショッキン グな䊅果を得たのである。これに関連して「協調 精神」(項目(1)一(3) を体得するものとしてスポ ーツをみている割合す淡路島調查の $83 \%$ に対し, 体育学部調查では $50 \%$ に满たない。また,「人間性 涵羕」(項目(1)一(1) にスポーツが資するとの見 方も淡路島調查が任倒的に高く $(79 \%)$, 体育学部 調查では $55 \%$ に過ぎない。

\section{考㖨}

社会規箷と価值の補強にスポーツが正機能を果 すに当って考古られる要件は，(1)スポーツが，本 来, 人间的侧面に関係していること，(2)ブライマ リー・グループとしてのスポーツ集団そのるのの 有している機能，および(3)スポーツ自体の内包す る競争・協同の效果に根さしている.しかし，ス ポーツは，本来，逆機能」をる兼和備えており， とくにスポーツ体験の豊富なるのがこれを強く指 摘するという結果を得たのである、それは，期 待・可能性としての「積極的役割を果すに当って 考えられる要件」が，必らずしす現実ではなく， 逆に現実の「場」においては深刻な問題点に直面 していることを意味するすのである。これらの文 眽において，スポーッが社会規筑と価值の㭪強に 果す正機能，が問われなければならない.
（1）社会規匴と価値の補強に及ぼすスポーツの 基本的目標スポーツは，状況（意味をるつ生活の 場面）に何らかの変化をるたらするのである，そ れは，言5までるなく，スポーツの技術的側面と 人間的側面を介して行なわれる.この变化を期待 するところにスポーツの目標 (goal) が位罱つけ られるのである.それ故，期待は哲学に支えられ ており，スポーツは目標に指问する行動といらこ とができるのである。具体的には，人閻性涵 (項目(1)一(1) をスポーッに求め $(70 \%)$, 㜣元る ことの意義（項目(1)一(2)）を体得し (77\%)，集 団の団桔（項目(1)一(6) に算する (76\%) ベくス ポーッの目標が位㻣つけられているのである.

ここに, 目橒指向的行動としてのスポーツが個 人とかかわりをるつ基本型がみられるのであり， 個人にスポーツが認容される選択過程のなかに, すでにスポーツの社会規範と価值とのかかわりの 基本的要件を汲みとることが可能なのである.こ の選択過程は三つの側面に求められる.

第一の篦択側面は，スポーツ参加者にとってス ポーツを選択することが自己の抱いている深遠な 目標仿有効な教育手段（項目イー氙）であると判 断される点にある.（筫料 9) い5まですなく， 〈手段一実践一目標の荟得〉は, 人間行動の 基本型である.

第二の選択側面は，スボーツ参加者にとってス ポーツを選択することが自己を導く価值の一貫的 な実現（項目イー(7)）において，通当であると判 断される点にある。（資料10）ここでい5価值と は，種々な犠牲または排除を伴 5 選抧過程におい て到達するに值すると思われる客体を指してお り, 欲求充足的な意味以上のるのを要求するもの である.

第三の巽択侧面は，スボーツ参加者にとってス

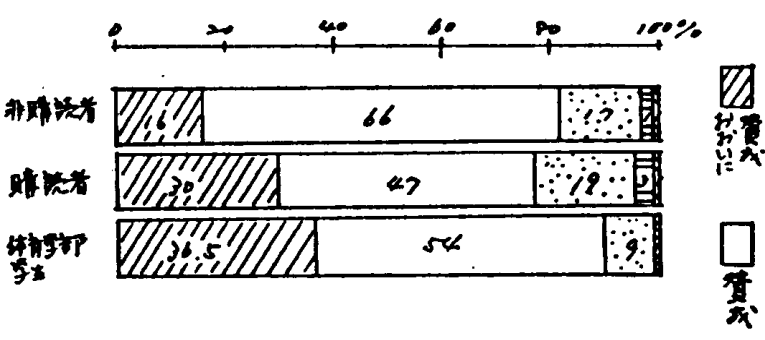

料9第一の丵択湖面 


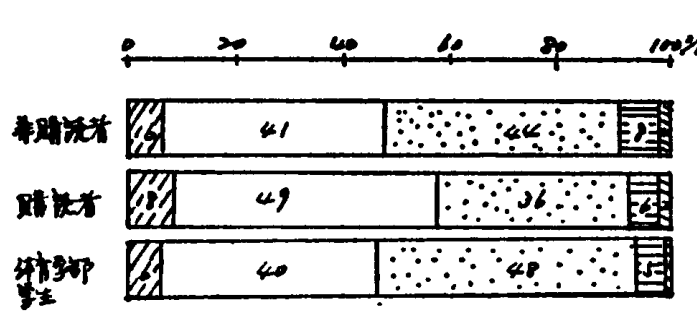

料10 第二の这択侧面

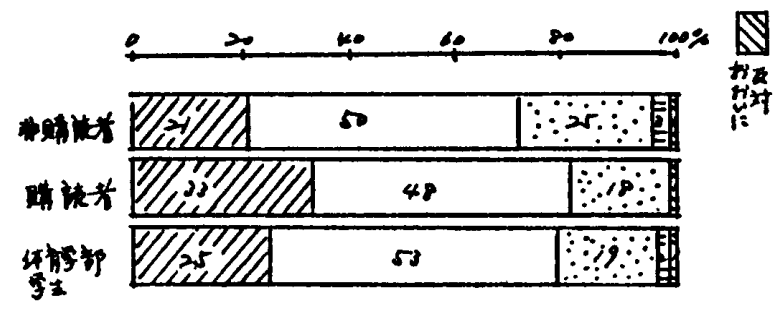

读料11第三の退択側面

ポーツが自己の欲求充足にうまく充当する（項目 イー-(2)）と判断される点にある。（資料11）それ は，かれにとってく手段一実践一目標の獲 得>過程において，スポーツが感情的に符合する ことを意味している.

それ故，選択側面の第一と第二はく合理的判 断>に負っており，第三のそれは燃える思いの 〈非合理的判断＞に根さしたものである.

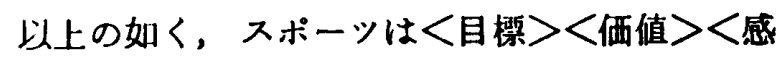
情>の三つの選択㑡面を通過したるのである.こ れらの側面はスボーッ参加者個人の問題であり， それが行政に移されるには外的条件(「場」「知識」 「仲間」など）の充足を待たなければならないこ とは言5まですない。しかし，スボーツが目標を 指台しそれが現実の環境で価値を付与され且つ楽 しいことに求められるとき，社会規筑と価值の補 強を促進する社会的人間形成への可能性が認めら れるのである．それ故に，スポーツは社会的に認 容された文化として位置つけられているのであ る. しかしながら，価佔が多粎化され且つ一時性 に特徽つけられる現代社会にあって、「スポーッは 軽卒で物事をよく考えない人間をつくる」といっ た現奏の問題点を無視することは許されないので ある.ナなわち，3つの選択側面の総合構成比率 はすべて 7割前後を示しているにも拘らす，スポ ーツは軽卒で物事をよく考えない人間をつくる
（項目回一(8)）ことす同時に指摘しているのであ る.そして，注目すべきはスポーツへの接触度合 いが高くなるにつれて，選択侧面の総合構成比率 恃高くなる反面，「蛏卒」を指摘する度合いも亥 いといらことである。この点は体有学部調宜にお いて「轾卒」を否定する割合が最も低い（淡路島

资料12 選択㑬面の構成此と「娃卒」の周係

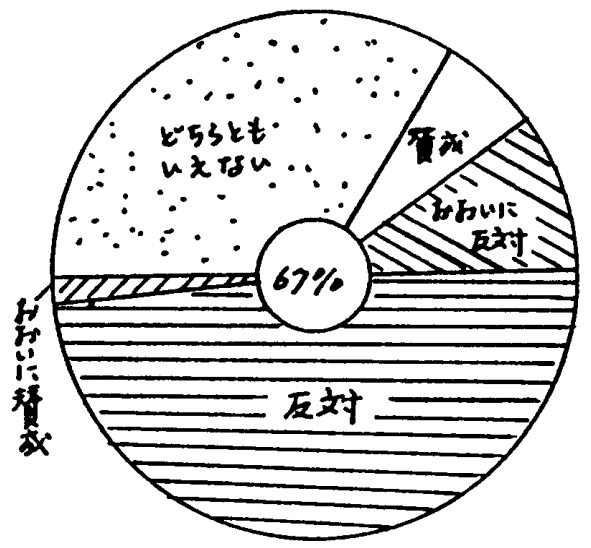

(价非睡镜者

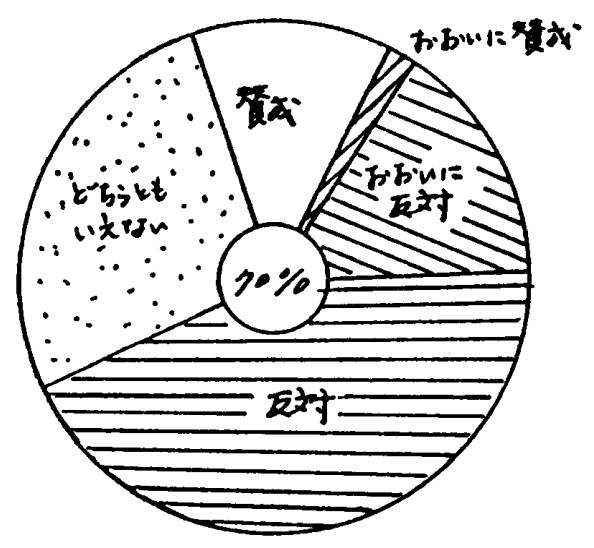

(口) 睡 諳 者

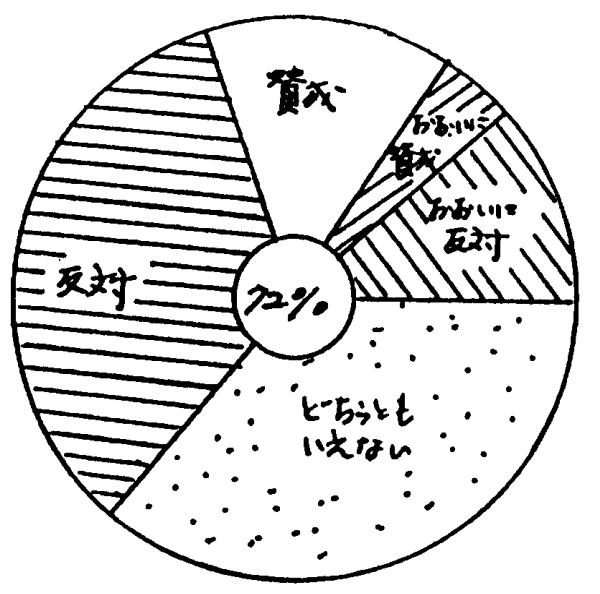

(6)体有学部学生 
調查に比較して約15\%) 点にも颢打ちされている のである(資料12).

（2）社会規範と価値の補強に与えるスポーツ集 団の役割一般にスポーツ集団は，顔と顔を付き合 わせた関係 (face-to-face relationship) に基つく 小集団である. 小集団は, (1少数者の直接接触を 基盤とし，(2)相互のコミュニケーションが行なわ れ，(3)特定の課題を遂行する目的をるった，(4)一 定期間存続し続ける集団であり，佃人に社会規笧 と価值の補強を強いる大きなプレッシャ一を果 す.それ故，スポーツ集団は，個人にとって社会 規㲎と価値の補強を現実のものとする主要な源泉 であり，個人と社会を結ぶきわ重要な媒介項 としての機能を果し得るのである。とくに，協調 性（項目イー(3)）を獾得し (70\%)，集団の団結 （項目イ一(6) を高める（76\%）なかで，個人は 社会規䇢と価值を自ら体得するへく位睓つけられ

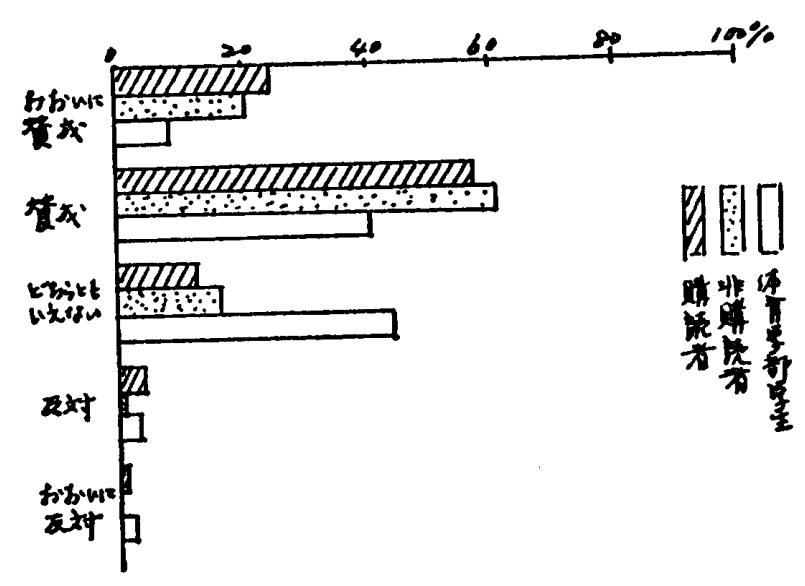

料13協調性獲得をスポーツと求める割合

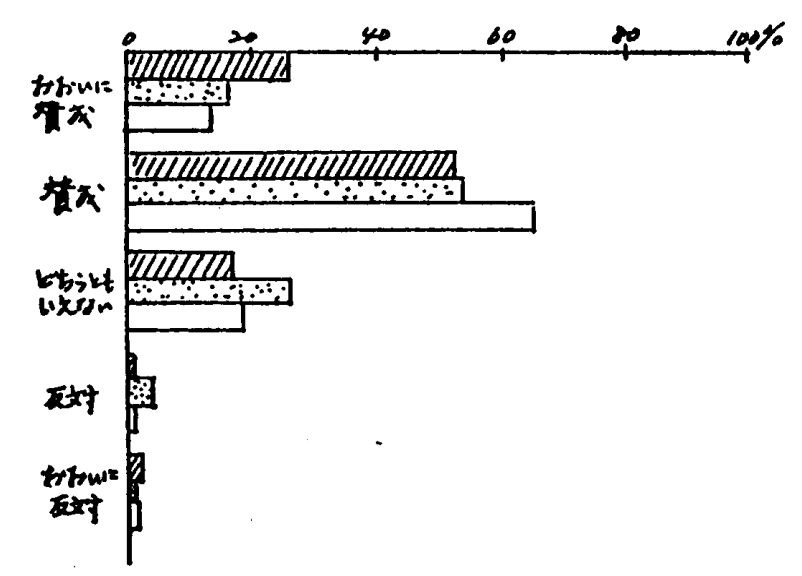

资料14 小隼団所属による団桔をスポーツ K求める剖合
ているのである、しかしながら，協調性獲得をス ポーツに水めるといっても，体育学部墭查では 「どちらでもない」とする数値がもっとも高く， 否定的指摘も淡路島調查に比较して﨎い（资料 13）同じことが小集団所屈による四結をスポーツ に求める割合においても認められる。（瓷料14）こ れらの瓷料は，スポーツ集団が佃人に対し社会規 笓と価偲の補強を現実のるのとする主要な源泉た り得ることは認めても，スポーッへの接触の程度 においてそれが現実には媒介項として逆機能の要 素をも含み得るものであることを示唆していると 解することが可能であろ5。

こうした事情は，現代社会の急激な変化のなか にあって，プライマリー・グループとしてのスポ 一ツ集団むつぎの如き背景と無縁ではあり得ない ことを意味している，すなわち，経済成長を主軸 とする社会の変化において，個人はその位㯰を見 失いがちであること．それは現代社会が技衍革新 - 都市化・核家族化 - 高学歴化 - 余暇の扗大 ・ 情 報化などの色彩を簧くする一方，個性の亦失・人 間柾外・世代間の断絶・コミュニティ意識の欠除 ・公害・自然破壊なとといった問題を背景にして いることに根さしている.このよ5な状況は，必 らずしもスポーツを通じて社会規範と価值の補強 が約束され難いとい5現実を示唆するに十分であ ろ5.すなわち、スポーツによるルールの通守（ 項目イー(9)), および行動の指標獲得（項目イー (8)）への信頼感はわれわれの予想に反するもので ある (とすに半分以下). 加えて, ルールの进守 にいたっては体育学部学生がもっとも否定的であ り，購読者がこれに秸いているのである。しか し，社会的行動の指標をスポーツに求める態度は 逆になっている。本来，ルールの连守と社会的行 動の指標は同一次元のものであるにも拘らず，調 査結果はこのよ5に跛行的様相を呈しているので ある、この事実は，とりるなおさず，スボーツに 対する期待・可能性にかける夢と現実の溝を示す ものであるすのである（凟料15）こ5した跛行 的様相は現代の大采社会状況下において，個人が すはや社会を肌て感じることが不可能になってい ることにその原因の一つを求めることが可能であ ろ5．すなわち，個人一社会とい5関係で個人と 
料15 スポーツによるルールの造守と社会的 行影指標の獲得割合
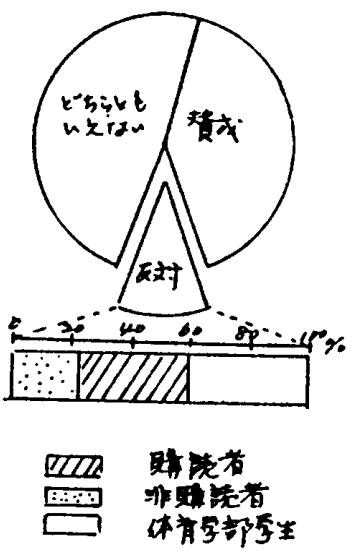

(1) ルールの㛵守

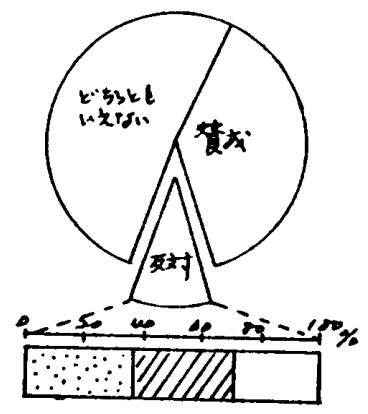

() 社会的行動指標

社会を理解しょうとする従来の概念図式は，いま や個人一小集団一社会とい5図式に変えなければ 現実性をもたないといえるのである，それは個人 にとって接触し得る数名ないし数十名の小集団を 通じてのみ，われわれは社会をとらえることが許 されることを意味している．換言すれば，個人は 小集団とい5フィルターを通して社会をみている のである.

ここに, プライマリー・グループの再評価とい 5 問題が生じてくる. それは個人の生活において 全人格的接触の許容篹围が狭まりつつある現代社 会への元愁にも似た人間性回復への叫びに根さし ている．現代社会の目的合理性を基盤とする多様 なセカンダリー・グループの圧倒的存在は, 個人 をしてその人格を奪い全体として統一ある人間の

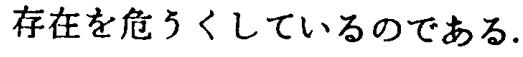

しかし，もっと現実的もしくは積極的次元にお。 いて小果団の役割は大きい.それは小集団が多様 な目的遂行にとって效果的な媒介項としての役割
を果し得ることに根さしている. スポーッ集団に ついていえば，それはスポーッの技術的側面と人 間的側面の修得を可能にしているのである. とく に, 後者に関して, スポーツ集団の有している規 筑と価值が参加者に与古る影響は大きく，セカン ダリー・グループ内での思考様式・行動様式の指 針の形成に温休としての影響力（項目イ一8）を もっているのである.それは，スポーッが社会棈 造と社会過程に打いて組樴化された“遊び”とし て，社会と社会生活を反映しているからにはかな らないからである。この意味で，スポーツは社会 規䇢と価值の補強もしくは減退に多大のかかわり を有しているのである.

しかしながら，現代社会の技術・知識の優先と い5跛行的状況はスポーツ集団をるその例外たる を許さず，その慗害を蕗呈していることは，既述 の如く, 調查結果の示すと扣りである.

（3）社会規籍と価值の補強に与之る競争・招同 の効果 競争 (competition) とは, 「同一の対象 の獲得・目標の達成に指向している複数の個人あ るいは集団が，相互に他より迅速に対象を擭得あ るいは目標を達成し，他に優越しよ5と指向して いる場合に，相互の間に成立する社会行動ならび に社会関係の非態10)」であり, ウィーぜはその指 向される対象を“対象指向的競争”，“主体指向的 競争”に大別している. 前者には，物算的財貨扰

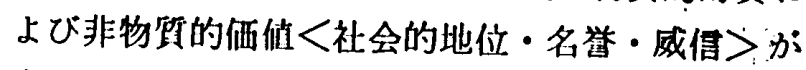
含まれ，後者は競争者自身の才能 - 能力の展閒 <運動競技における新記録の樹立・得点の獲得な どを>含む11)。ささに，スポーツは個人またはテ ィームが他の倜人またはティームに優越している ことを証明することにほかならない。

スポーツの場でみられる主体指向的競争は，多 かれ少なかれ他者の満足の排除とい5 形をとる.

しかしながら，競争は相手の妨害または挫折を主 たる指向とせず，課題遂行に指向するるのであ る. 同時に, 競争はルールの莩守とい5領域内で 行動が発現される.ここに，闑争とは別の次元の 競争の意義が認められるのである。閵争も競争。 ともに課題遂行過程において障害物を排除すると い5形をとるが，前者の結果が生活を左右するの に対し，後者のそれは生活に直接の影響をむたら 
さないそそはく遊び〉としてのスポーツの場で の競争において明らかである.スポーツが，本 来，〈避び〉として“非日常的”なるのとして， 位置つけられる所以である。ここに競争によるメ リットが隠されているのである.

それ性競争行為に捕ける協同とい5概念によっ て理解される。すなわち，協同 (cooperation) と は，「複数の倜人または集団か，其通の目的また は対象を獲得・達成するために，多かれ少なかれ 組織的な方法によって，相互の活動を調整し，北 同の効果をるたらそ5とするよ5な社会行動・社 会関係(2)」である。それは，スポーツ集団に拈い ては課題遂行過程での各プレイヤー間の行為の調 整・統合として受けとられる.として，スポーツ の場では仕接的協同が主体であり，颜と顔をつき 合わせた関係 (face-to-face-relationship) が維持 されるのである.

こ5した直接的協同の意義は大きい，とくに現 代社会の急澈な变化の波は, 一般に協同者を地理 的に隔絶し，その結果間接的にしか接触し得ず部 分的協同もしくは間接的協同を余儀なくしている のである. その結果，全人格的接触を弱め，人間 性を奪５傾向を否定し得ないのである．それは協 同が，本来，自発性に基す゚いたすのであるにも拘 らず，強制に求められつつあることを意味する。 この意味からも，小集団内での主体的競争とその 過程での直接的協同の及ぼす社会規箸と価值の補 強への役割が認められるのである.それはスポー ッ集団において顕著にみられる特性であり，とく 飞体得にその根扔を見い出すことが可能である.

競争と協同は，スポーツの場では括よそ次の如 き関係を有しているすのとみることができる。す なわち，個人が证を競う場合には競争関係が俓先 する傾向を有し，集団（ティーム）で糋を競5場 合には協同関係が嗳先する倾问を有するが，こ5 した関係は背反関係にあるのではなく，種目によ って一方の特性がより強く出てくるというほどの 意味である。

スポーツの場での競争・協同関係は，社会規範 と価值の補強に積極的意義を果している．少なく とも果す可能性をもっていると言わなければなら ない、それはこ5した関係のなかで，スポーッ参 加者は特定の規箱と価值を好ましい隹度（attitude）として身につけていくからにほかならないか らである。しかしながら，大策社会状況下の現実 のスポーツをとりまく環境は，スポーツを羊なる “遊び”として非日常的な場に求め奞い要素を除

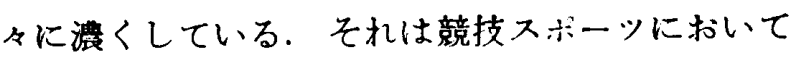
は技術の高度化とそれに伴5 日常的な報酬を期待 し得る場として，またレクリェーション・スポー ツにおいても現在のそ机は経済的・時間的余裕を 满し得るもののみが，主としてスポーツの場に参 加し得るという意味でともにェリート化されてい る点に求めら机る。そ机故，現実のスポーツは多 少なりとも日常性の5えに成立しておりここに スポーツに対する期待・可能性が跛行的様相を．吕 する一因を㤎め得るのである。すなわち，社会規 箱と価值の補強に及ほすスポーツの正機能につい ての支持率は全体で64.9\%であるものの，体育学 部学生のそれは最も低く58.7\%となっているので ある，同様に，その逆機能を指摘するものの制合 は全体で $12.8 \%$ に過ぎないものの，体育学部学生 が最も亮く $14.4 \%$ 示しているのである.すなわ ち、スポーツに接触する度合いが高いはどスポー ッのもっている期待・可能性と現実の落差を指摘 しており，われわれにとってこの落差を冷静にと らえる智が要求されるのである。それは，とり もなおさず，現実のスポーツが競争によるメリッ 卜を指向しながらる閏争への危険性をはらんでい ることの認識にほかならない。

\section{結語}

知識・技術優先の現代社会にあって人間がその 能力の一部分をしか発揮できない傾向を深めつつ ある今日，社会規䈤と価值の補強に及ぽすスポー ッの積極的機能が一応評価されている，しかしな がら，それは調㳊結赑の示すとおり，跛行的様相 を呈しているのである．そ机は「期待・可能性」 としてのスポーツと現実のスポーツによる社会規 匴と価值の減退の間の落差がようしならさるるの に発展しつつあることを示唆している。

それ故, 結果としてのスポーツの社会規範と価 值に及ほ譏能についての考察か，改めて求めら れなけ机ばなないであら5。その5えで社会規 


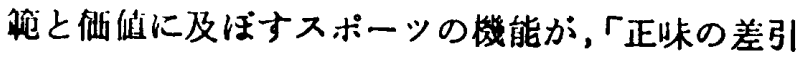
き勘定」として議論の対象となり得るが，当面は とりもなおさず, “中䇚围の理諭”（T．パーソン ズを目さす必要があろ5。

\section{参考文献}

1）石川旦「アメリカとおける体育目標の概念棬成に 関与る研究 (1920-1969)」「体育科辞典』 p. 444. 第一法規出版，1963．1910年から1962年まで飞出版 された体育学春のうちスポーツと社会規筑と洒值の 間連性はつぎのと打りである.すなわち、スポーツ

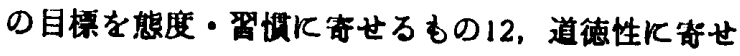

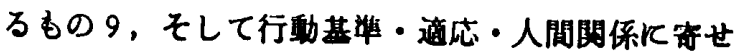
ろあのは，実に18K连しているのである.

2）「学校体操教授要目」大正 2 .

3）麇島研究所出版会「社会科学大事典」Vol. 9. P. 306. 1970.
4) Weber M.; Soziologishe Grundbegriff, Wirtschaft und Gesellschaft. 阿閒吉男他訳 『社会学 の基整概念」 pp. 39-40. ，角川文庫， 1953.

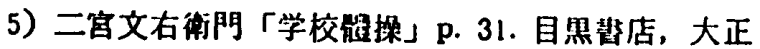
15.

6) Merton R. K.; Social Theory and Social Structure, 森東吾他訳「社会理詥と社会粠造」pp. 16 -77，みすず聿房，1961.

7) Merton R. K.; 同上.

8）「スポーツ淡路」紙は，蛇持茂富氏が相集発行し ているコミュニティ・スポーツ新間である，淡路禺 全域をかバーし，島内で行なわれる草野球から対外 試合までを網羅している. 昭和49年 3 月現在で発行 回数1073回を数えている(月3 回発行).

9）理想と現実，るしくは期待 - 可能性と現実の矛盾

10）「社会学辞典」P. 159, 有斐㜀， 1958.

11) 同上, p. 159-160. 1958.

12）同上, p. 161. 1958. 